University of Nebraska - Lincoln

DigitalCommons@University of Nebraska - Lincoln

Determination of residue levels of the avicide 3-chloro-4-methylaniline hydrochloride in red-winged blackbirds (Agelaius phoeniceus) by gas chromatography-tandem mass spectrometry

\author{
David A. Goldade \\ USDA APHIS Wildlife Services, David.A.Goldade@aphis.usda.gov \\ Kirsten R. Kim \\ USDA APHIS Wildlife Services \\ James C. Carlson \\ USDA APHIS Wildlife Services, james.c.carlson@aphis.usda.gov \\ Steven F. Volker \\ USDA APHIS Wildlife Services
}
Follow this and additional works at: https://digitalcommons.unl.edu/icwdm_usdanwrc
Part of the Life Sciences Commons

\footnotetext{
Goldade, David A.; Kim, Kirsten R.; Carlson, James C.; and Volker, Steven F., "Determination of residue levels of the avicide 3-chloro-4-methylaniline hydrochloride in red-winged blackbirds (Agelaius phoeniceus) by gas chromatography-tandem mass spectrometry" (2019). USDA National Wildlife Research Center - Staff Publications. 2220.

https://digitalcommons.unl.edu/icwdm_usdanwrc/2220
}

This Article is brought to you for free and open access by the U.S. Department of Agriculture: Animal and Plant Health Inspection Service at DigitalCommons@University of Nebraska - Lincoln. It has been accepted for inclusion in USDA National Wildlife Research Center - Staff Publications by an authorized administrator of DigitalCommons@University of Nebraska - Lincoln. 


\title{
Determination of residue levels of the avicide 3-chloro-4-methylaniline hydrochloride in red-winged blackbirds (Agelaius phoeniceus) by gas chromatography-tandem mass spectrometry
}

\author{
David A. Goldade*, Kirsten R. Kim, James C. Carlson, Steven F. Volker \\ USDA/APHIS/WS National Wildlife Research Center, 4101 LaPorte Avenue, Fort Collins, CO, United States of America
}

\section{A R T I C L E I N F O}

\section{Keywords:}

Avicide

CPTH

DRC-1339

Red-winged blackbirds

GC-MS-MS

\begin{abstract}
A B S T R A C T
The avicide 3-chloro-4-methylanaline hydrochloride (chloro-p-toluidine hydrochloride, CPTH, DRC-1339) is used to control pest bird species that damage agricultural crops. A specific and sensitive gas chromatographytandem mass spectrometry method was developed and validated for the determination of CPTH in avian breast muscle, GI tract, kidney, and liver. Tissue samples were extracted with a solution of acidified water and acetonitrile. The sample was made basic and cleaned up with a combination of liquid-liquid partitioning and solid phase extraction. Separation was achieved using a HP-5 ultra-inert GC column (15 M, $0.25 \mu \mathrm{m}$ film) with detection on a triple quadrupole mass spectrometer in multiple reaction monitoring (MRM) mode. The monitored transition for CPTH was $m / z \quad 140.9 \rightarrow 106.2$ for quantitation and $139.9 \rightarrow 105.2$ and $139.9 \rightarrow 77.2$ for confirmation. The linear range was 5 to $5000 \mathrm{ng} / \mathrm{mL}$. The precision for the determination of CPTH in all tissues averaged $7.2 \%$ and the accuracy averaged $6.7 \%$. The recovery of CPTH fortified at 5 different levels averaged $101 \%$ in liver, $98.8 \%$ in GI tract, $92.9 \%$ in breast muscle, and $87.9 \%$ in kidney. The established method was successfully used to determine CPTH residue levels in red-winged blackbirds exposed to three different doses of CPTH.
\end{abstract}

\section{Introduction}

3-Chloro-4-methylaniline hydrochloride (3-chloro-p-toluidine hydrochloride, DRC-1339, CPTH) is a slow-acting toxicant in avians. Because the time to death (1-3 days) is well after exposure, very few analyses of collected carcasses have found significant CPTH residues $[1,2]$. Public concerns surround the possibility for secondary hazard or non-target exposures from the use of CPTH. CPTH intoxication is often suspected when mysterious bird deaths are noted by members of the general public or conservation groups.

Detection of CPTH exposure in both target and non-target birds has been very problematic. Very early efforts to detect exposure were based on necropsies of the carcasses with examination to attempt to detect physiological indicators of exposure such as the accumulation of uric acid deposits [1]. Such deposits were thought to be indicative of CPTH exposure [3]. More recent advances have seen the use of deuterated standards and gas chromatography with mass spectrometry for the detection of CPTH residues at low levels in the tissues of exposed birds [4]. This newer technique has improved performance over older techniques with the added benefit of very good analytical sensitivity. The reported limit of detection was $12 \mathrm{ng} / \mathrm{g}$ for breast muscle and $25 \mathrm{ng} / \mathrm{g}$ for GI tract [4]. Despite these improvements, difficulties with noisy baselines and low extraction efficiencies led to very few verified exposures which were also prone to false positives.

In one study with grackles, the concentration present in the tissues was found to increase with increasing exposure levels [1]. Given that the anticipated exposure dose for a red-winged blackbird would be around $25 \mathrm{mg} / \mathrm{kg}$ [5], the odds of detecting exposure in tissues from these birds are very low. Once a bird is exposed to a lethal dose of $\mathrm{CPTH}$, time to death is typically 1 to 2 days. The observed half-life of elimination for CPTH has been estimated to be $5.4 \mathrm{~h}$ in sensitive species [6]. Therefore, detection of a lethal exposure to CPTH is almost

\footnotetext{
Competing interest statement: The authors have no competing interests to the publication of this work.

This research was supported by the intramural research program of the U.S. Department of Agriculture, Animal and Plant Health Inspection Service.

Disclaimer: The findings and conclusions in this preliminary publication have not been formally disseminated by the U.S. Department of Agriculture and should not be construed to represent any agency determination or policy.

* Corresponding author.

E-mail address: David.A.Goldade@aphis.usda.gov (D.A. Goldade).
} 
impossible to achieve as the toxicant has left the body of the bird prior to death. Use of tandem mass spectrometry coupled with improvements to the extraction techniques used could produce a more sensitive method which could detect these residues.

\section{Materials and methods}

\subsection{Trapping of birds}

Thirty-seven red-winged blackbirds (Agelaius phoeniceus) of mixed genders were trapped from wild populations in Colorado (USFWS Permit Number MB019065-3) and transported to the National Wildlife Research Center's Outdoor Animal Research Facility. The birds were held in quarantine for not $<7$ days. They were maintained in group housing during quarantine and given free access to water and a maintenance diet through the study. All procedures involving animals were carried out with the approval of the NWRC Animal Care and Use Committee (NWRC protocol QA-2708).

\subsection{Purification of $C P T H$}

CPTH is sold as Compound DRC-1339 Concentrate in several formulated products for use by certified pesticide applicators. The purity limits for these products are 94.1 to $99.9 \%$ CPTH. Significant impurities within the material could confound the results of these dosing tests. Therefore, the material was purified before use in the in-vivo portion of the study.

All chemicals were obtained from Fisher Scientific (Waltham, MA, USA) unless otherwise specified. One half kilogram of Compound DRC1339 Concentrate (PM Resources, Fort worth, TX, USA) was weighed into a 2-L beaker. Methanol $(1.5 \mathrm{~L})$ was added and heated to approximately $40^{\circ} \mathrm{C}$ on a stirring hot plate. To this was stirred in $20 \mathrm{~mL}$ of a $1 \mathrm{~N}$ $\mathrm{HCl}$ solution in water and $30 \mathrm{~g}$ of activated charcoal. The solution was allowed to stir for approximately $1 \mathrm{~h}$ until it was nearly colorless. It was then filtered through a Whatman \#1 filter paper in a Buchner funnel, reserving the liquid. The liquid was evaporated in a rotary evaporator under vacuum until a wet powder consistency was achieved. The powder slurry was filtered through a Whatman \#1 filter on a Buchner funnel, with the liquid being reserved. The powder was covered with approximately $200 \mathrm{~mL}$ of acetonitrile and, after a 2 minute wait, vacuum was applied. The filtrate was discarded to waste. The process of rotary evaporation and filtering was repeated with the methanol solution until no more powder was obtained. The white, crystalline product was allowed to dry in a fume hood overnight. The purified CPTH powder was stored in a refrigerator at $4{ }^{\circ} \mathrm{C}$ until used. Purity was confirmed by HPLC-UV prior to the initiation of the in-vivo portion of the study and found to be $99.9 \%$.

\subsection{Synthesis of surrogate compound}

A surrogate compound was used for all chromatographic analyses. As a deuterated material was not commercially available, it was synthesized. Deuterated $d_{6}$-CPTH was synthesized following the procedures in Hurlbut et al. [7] with modification of one step. The initial nitration reaction was accomplished using sodium mordenite (Zeolist International, Kansas City, KS, USA) following the procedures established by Smith and Fry [8]. The mordenite increased the yield of the p-nitrotoluene significantly over the original procedure. The reactions yielded a very pale yellow powder with a purity of $>99 \%$ by GC/MS.

\subsection{Administration of dose}

Red-winged blackbirds were randomly assigned to test or control groups and exposed to one of three doses of the purified CPTH ( 8 birds per treatment level) via oral gavage and held for three days. Oral gavage was accomplished by using a \#9 gelatin capsule containing the appropriate mass of CPTH and packed with D-mannitol (an inert material) to fill the unused space in the capsule. The birds were held in a supine position and the capsule was delivered using a stainless steel dosing syringe. Dosage levels were approximately 12.5, 25, and $37.5 \mathrm{mg} / \mathrm{kg}$ based on an average weight of $60 \mathrm{~g}$ for a red-winged blackbird. A control group of 8 birds received a capsule containing only D-mannitol. Birds in both the test and control groups were held in individual cages for the remainder of the study. Twice daily, the condition of the birds was observed and noted. Deceased birds were removed; their weight and the time were recorded. No individuals from the control group expired during the exposure period. All birds that survived the full 3-day exposure period were euthanized with $\mathrm{CO}_{2}$. All birds were euthanized humanely in accordance with American Veterinary Medical Association standards and practices.

\subsection{Tissue collection}

All birds, including the control group, were necropsied to remove tissue samples for analysis. An incision was made in the skin covering the abdomen, and the birds were skinned completely. A lateral incision was then made at the base of the breast bone and a pair of scissors used to cut the breast bone on each side. The kidneys, GI tract (from esophagus to cloaca with contents included), liver, and a portion of the breast muscle were removed from each bird and individually flash frozen with liquid nitrogen. The samples were ground to a fine powder with a chilled mortar and pestle in the case of kidney and liver samples or through the use of a freezer mill (SPEX CertiPrep, Metuchen, NJ, USA) and stored in individual containers. Kidney samples were stored at $-80^{\circ} \mathrm{C}$. All other samples were stored at $-30^{\circ} \mathrm{C}$.

\subsection{Gas chromatography-mass spectrometry analysis}

The GI tract, liver, kidney, and breast muscle were analyzed for $\mathrm{CPTH}$ content by gas chromatography/tandem mass spectrometry. During the extraction process the CPTH was converted from the hydrochloride to the free base form (CPT). Although CPT was the form detected by the mass spectrometer, all results were reported in terms of CPTH (Fig. 1).

The homogenized samples $(0.2$ to $0.5 \mathrm{~g})$ were fortified with a surrogate compound $\left(d_{6}-\mathrm{CPTH}\right)$ and extracted with $2.5 \mathrm{~mL}$ of $20 \%$ acetonitrile/80\% $1 \mathrm{M}$ hydrochloric acid. The sample extract was made basic ( $\mathrm{pH}$ approximately 10) with the addition of $2.5 \mathrm{~mL}$ of $2 \mathrm{M}$ sodium hydroxide which converted the CPTH to CPT and extracted with three $3 \mathrm{~mL}$ aliquots of hexane. The hexane extract was cleaned-up using a silica solid phase extraction (SPE) cartridge (Biotage, Charlotte, NC). The CPT was eluted from the SPE with $2 \mathrm{~mL}$ of a $50 \mu \mathrm{g} / \mathrm{mL}$ solution of $p$-toluidine (Sigma Aldrich, St. Louis, MO, USA) in $n$-butyl acetate. Analysis was performed using an Agilent 7890A Gas Chromatograph attached to an Agilent 7000B QQQ Mass Spectrometer (Santa Clara, CA, USA). Separation was achieved using a $15 \mathrm{~m} \times 0.25 \mathrm{~mm} \mathrm{ID}, 0.250 \mu \mathrm{m}$, DB5-MS UI column (Agilent Technologies, Santa Clara, CA, USA) connected through a purged ultimate union to a $0.65 \mathrm{~m}$ length of $0.15 \mathrm{~mm}$ ID fused silica. This arrangement allowed the use of a post-run backflush to minimize contamination of the detector with high boiling temperature matrix components. Other instrument parameters are in Table 1 .

\subsection{Method validation}

The method was validated by evaluating the following parameters: selectivity, limits of detection (DL) and quantification (QL), linearity, accuracy, recovery. When not specified, result values were tabulated and analyzed using Microsoft Excel 15.0 (Microsoft Corp, Redmond, WA). 


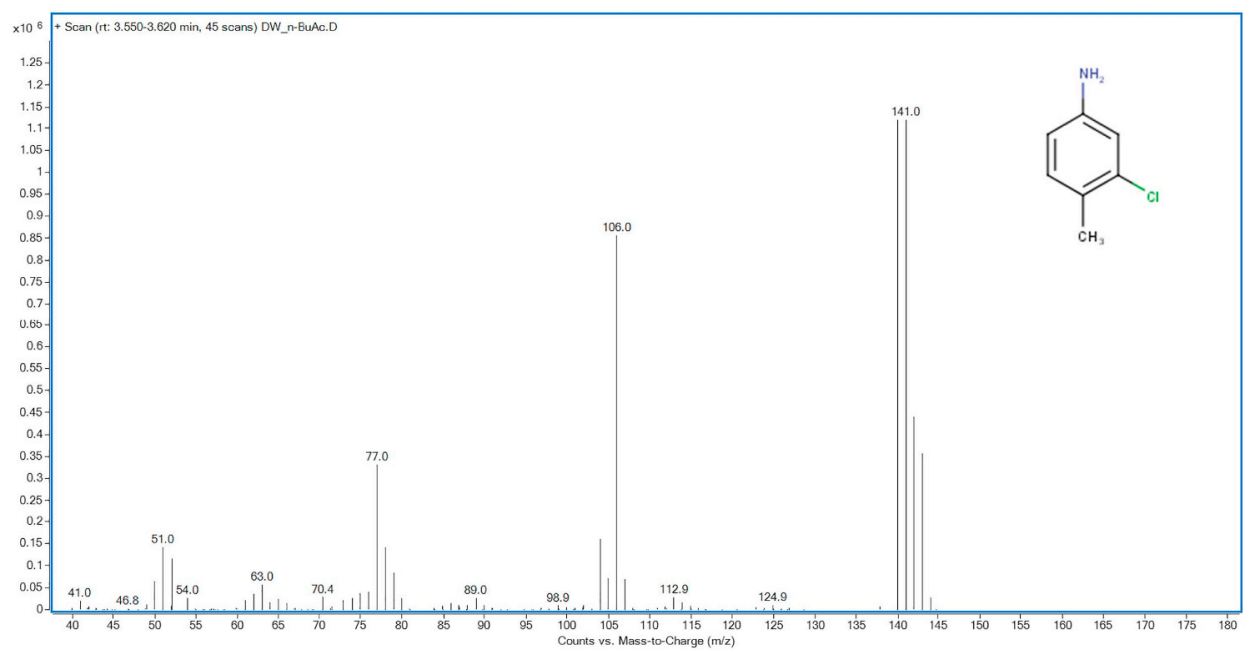

Fig. 1. Mass spectrum of CPTH.

Table 1

Gas chromatograph/mass spectrometer conditions.

\begin{tabular}{|c|c|c|c|c|}
\hline \multicolumn{2}{|l|}{ Carrier gas: } & \multicolumn{3}{|l|}{ Helium } \\
\hline \multicolumn{2}{|c|}{ Inlet liner: } & \multicolumn{3}{|c|}{ Ultra-inert liner, splitless, single taper with wool } \\
\hline \multicolumn{2}{|c|}{ Injection port: } & \multicolumn{3}{|c|}{$250{ }^{\circ} \mathrm{C}$; pulsed splitless; $15.9 \mathrm{psi}$; constant-flow } \\
\hline \multicolumn{2}{|c|}{ Injector pressure: } & \multicolumn{3}{|c|}{$\begin{array}{l}\text { Pulse at } 70 \text { psi for } 1 \mathrm{~min} \text {; split vent at } 60 \mathrm{~mL} / \mathrm{min} \text { at } \\
2.5 \mathrm{~min}\end{array}$} \\
\hline & \multicolumn{3}{|c|}{$1 \mu \mathrm{L}$} \\
\hline & \multicolumn{4}{|c|}{ Temperature program: } \\
\hline \multicolumn{2}{|c|}{ Time (min) } & Temperature $\left({ }^{\circ} \mathrm{C}\right)$ & \multicolumn{2}{|r|}{ Rate $\left({ }^{\circ} \mathrm{C} / \mathrm{min}\right)$} \\
\hline \multicolumn{2}{|c|}{0.00} & 70 & \multicolumn{2}{|r|}{ - $\quad$ - } \\
\hline 2.00 & & 70 & \multicolumn{2}{|r|}{-} \\
\hline 7.25 & & 175 & \multicolumn{2}{|r|}{20} \\
\hline 8.50 & & 300 & \multicolumn{2}{|r|}{100} \\
\hline 12.00 & & 300 & \multicolumn{2}{|r|}{-} \\
\hline \multicolumn{2}{|c|}{ Collision cell: } & \multicolumn{3}{|c|}{$\begin{array}{l}2.25 \mathrm{~mL} / \mathrm{min} \text { He quench gas; } 1.5 \mathrm{~mL} / \mathrm{min} \text { nitrogen } \\
\text { collision gas }\end{array}$} \\
\hline \multicolumn{2}{|c|}{ Ion source: } & \multicolumn{3}{|c|}{ Electron impact } \\
\hline \multicolumn{2}{|c|}{ Source temperature: } & \multicolumn{3}{|l|}{$230^{\circ} \mathrm{C}$} \\
\hline \multicolumn{2}{|c|}{ Solvent delay: } & \multicolumn{3}{|l|}{$4.5 \mathrm{~min}$} \\
\hline Compound & $\begin{array}{l}\text { Precursor ion } \\
(m / z)\end{array}$ & $\begin{array}{l}\text { Product ion } \\
(\mathrm{m} / \mathrm{z})\end{array}$ & Dwell (ms) & $\begin{array}{l}\text { Collision energy } \\
\text { (V) }\end{array}$ \\
\hline$d_{6}-\mathrm{CPTH}$ & 148.9 & 112.2 & 20 & 19 \\
\hline$d_{6}-\mathrm{CPTH}$ & 146.9 & 112.2 & 40 & 15 \\
\hline$d_{6}$-СРТН & 112.2 & 81.2 & 20 & 19 \\
\hline СРТН & 140.9 & 106.2 & 50 & 15.5 \\
\hline СРTH & 139.9 & 105.2 & 20 & 16 \\
\hline СРTH & 139.9 & 77.2 & 20 & 19 \\
\hline
\end{tabular}

\subsubsection{Control tissues}

The repeatability and performance of the method was assessed using a surrogate avian species. Coturnix quail (Coturnix japonica) were used as control matrix for the preparation of fortified quality control samples. Quail were chosen due to the ability to readily obtain large quantities of tissue from each individual. The red-winged blackbirds are much smaller and it would have taken a large number of individuals to provide enough matrix for quality control purposes. Both birds are granivores, and quail were an adequate representative of red-winged blackbirds. Quail were purchased from a hatchery in Colorado and their tissues were processed according to the procedures outlined above.

\subsubsection{Selectivity}

Selectivity of the method was evaluated by analyzing 7 replicate samples of breast muscle, GI tract, liver, and kidney tissue from commercially raised Coturnix quail. Potential interferences were assessed at the retention time of CPTH by comparing the analytical response in the control samples to samples fortified near the QL.

\subsubsection{Detection and quantification limits}

The detection limit (DL) for CPTH in red-winged blackbird tissues was estimated from the mean chromatographic response of control samples compared to control samples that had been fortified to $20 \mathrm{ng} / \mathrm{g}$ with CPTH for GI tract, liver, and breast muscle or $50 \mathrm{ng} / \mathrm{g}$ with CPTH for kidney. The DL was defined as the concentration of CPTH required to generate a signal equal to $3 \times$ the baseline noise (measured peak-topeak) observed in the baseline at the retention time of CPT in the control samples. The quantitation limit (QL) for CPTH in red-winged blackbird tissues was estimated in a similar fashion to as the DL with the multiplier of $10 \times$ baseline noise used instead of $3 \times$.

\subsubsection{Linearity}

Two sets of six calibration standard solutions were prepared ranging from $5.15 \mathrm{ng} / \mathrm{mL}$ to $5300 \mathrm{ng} / \mathrm{mL}$. The standards were made basic by the addition of $2 \mathrm{M}$ sodium hydroxide which converted the CPTH to CPT and extracted with a solution of $50 \mu \mathrm{g} / \mathrm{mL} p$-toluidine in $n$-butyl acetate. Each standard was injected in triplicate; the response ratio of CPT area to $d_{6}$-CPT area was plotted against relative concentration. A weighted $(1 / \mathrm{x})$ quadratic regression was performed on the data set.

The accuracy of the calibration standards was determined for each data set by calculating the observed concentration of each standard in the calibration curve using the regression equation. This calculated observed concentration is then compared to the theoretical concentration of the standard to determine the accuracy as a percentage.

\subsubsection{Recovery}

A minimum of 7 replicates at each fortification level were prepared by adding an appropriate aliquot of a fortification solution to a $500 \mathrm{mg}$ sample of control quail tissue. Due to the limited sample size of the RWBB kidneys, the mass of sample used for quality control purposes was reduced to $200 \mathrm{mg}$ to more accurately reflect the sample masses of the study samples. Control quail liver, GI tract, and breast muscle were fortified at 20,50,100,300, and $1000 \mathrm{ng} / \mathrm{g}$. Control quail kidney was fortified at 50, 125, 250, 750, and $2500 \mathrm{ng} / \mathrm{g}$.

The accuracy of the method was determined by calculating the relative error of the mean observed concentration at each fortification level. This value was calculated by determining the absolute value of the difference between observed concentration and target concentration and dividing by the target concentration.

\subsubsection{Statistical methods}

The statistical model used to evaluate the variance of the quality 


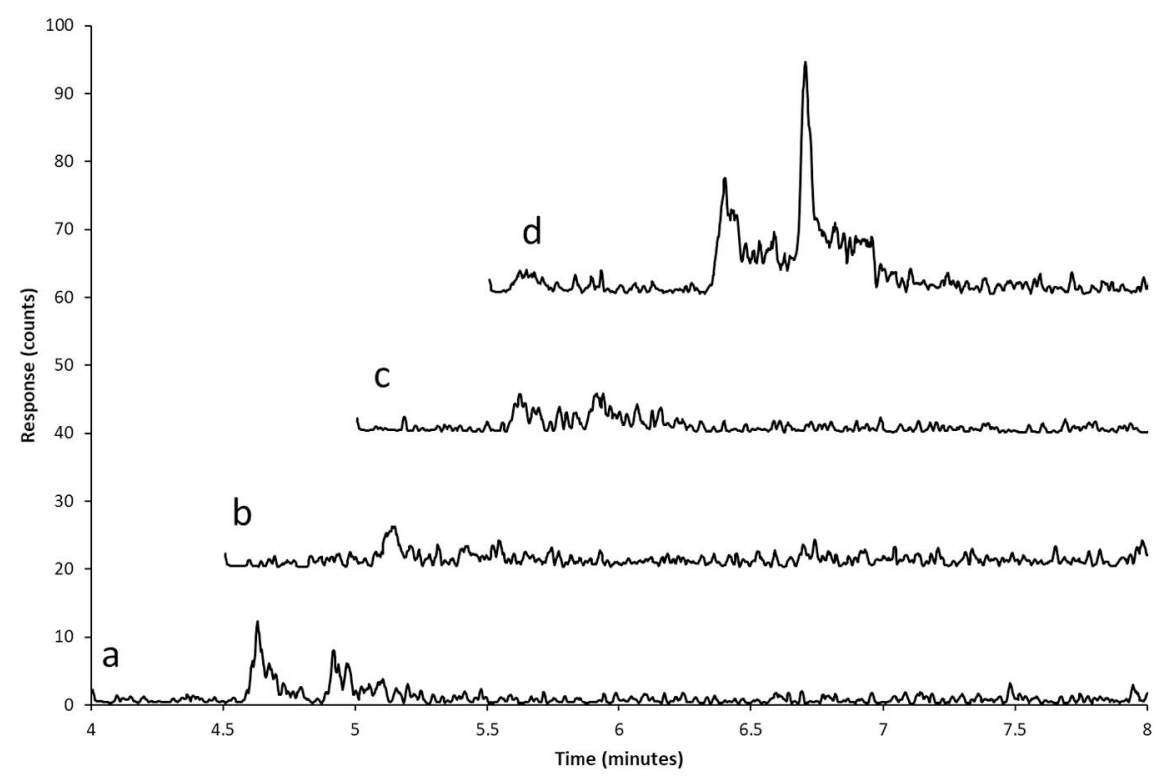

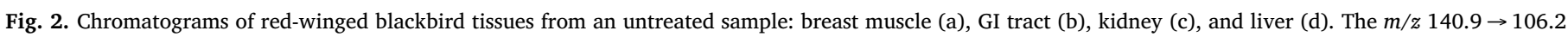
MRM transition is shown.

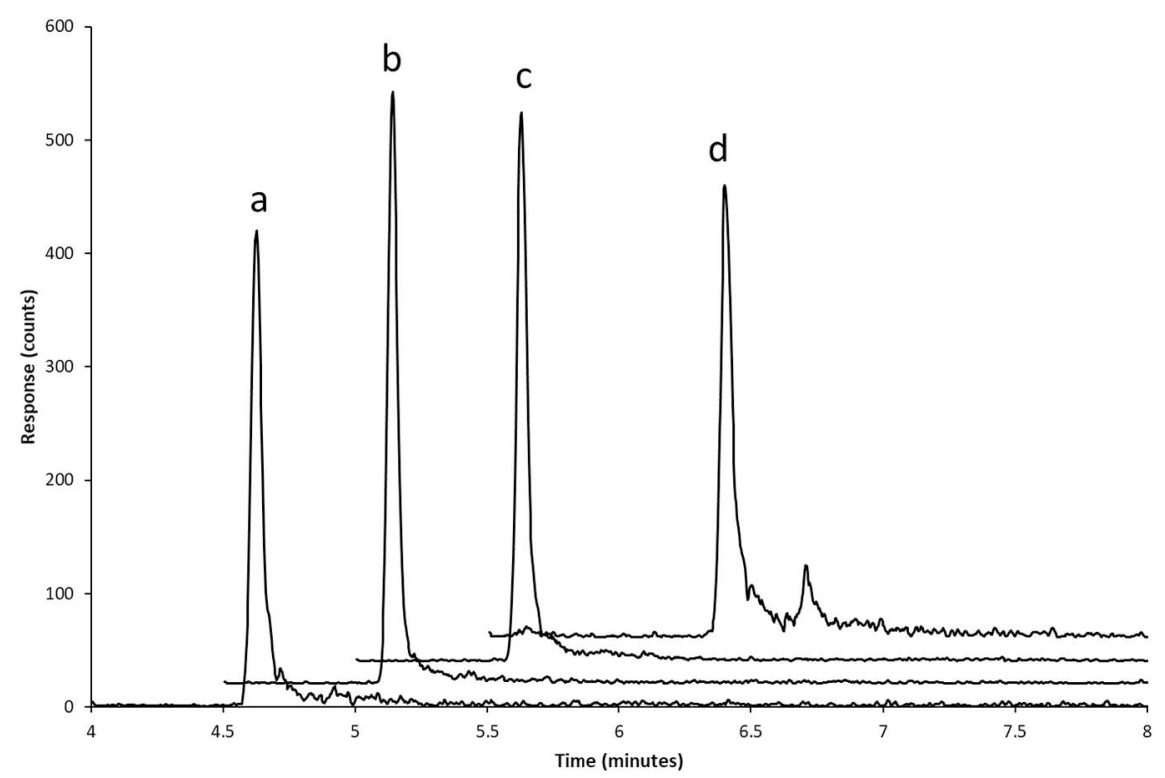

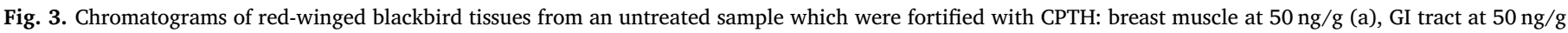
(b), liver at $50 \mathrm{ng} / \mathrm{g}$ (c), and kidney at $125 \mathrm{ng} / \mathrm{g}$ (d). The $\mathrm{m} / z 140.9 \rightarrow 106.2 \mathrm{MRM}$ transition is shown.

control data was SAS's General Linear Model (GLM) (SAS Institute, Inc., Cary, NC). The GLM performs analysis of variance by using least squares regression to fit general linear models. The response was the percent recovery of the quality control samples. The fixed effects were the tissue matrix type and the fortification level. The interaction between fixed effects was also evaluated.

\section{Results and discussion}

\subsection{Method development}

A deuterated form of CPTH $\left(d_{6}-\mathrm{CPTH}\right)$ was selected as the internal standard (IS) for this method. Multiple reaction monitoring (MRM) transition pairs were selected for both CPT and $d_{6}$-CPT and optimized with respect to collision energy. The dwell values were weighted towards the quantitative transition for each compound. The quantitative transition for CPT was $m / z 140.9 \rightarrow 106.2$ while the $d_{6}$-CPTH transition was $m / z 146.9 \rightarrow 112.2$.

CPTH is the hydrochloride salt of the free base CPT. During method development, this chemistry was exploited to enable extraction of the CPTH as its free base CPT. This also served to remove a significant amount of water soluble matrix components and dissolved the CPT in a GC friendly solvent. The use of a normal phase SPE provided further clean-up of the sample extract. A solution of $p$-toluidine was used as the final sample solvent. CPT can react with active sites in the GC inlet. Use of a competing compound acted as an analyte protectant and produced 


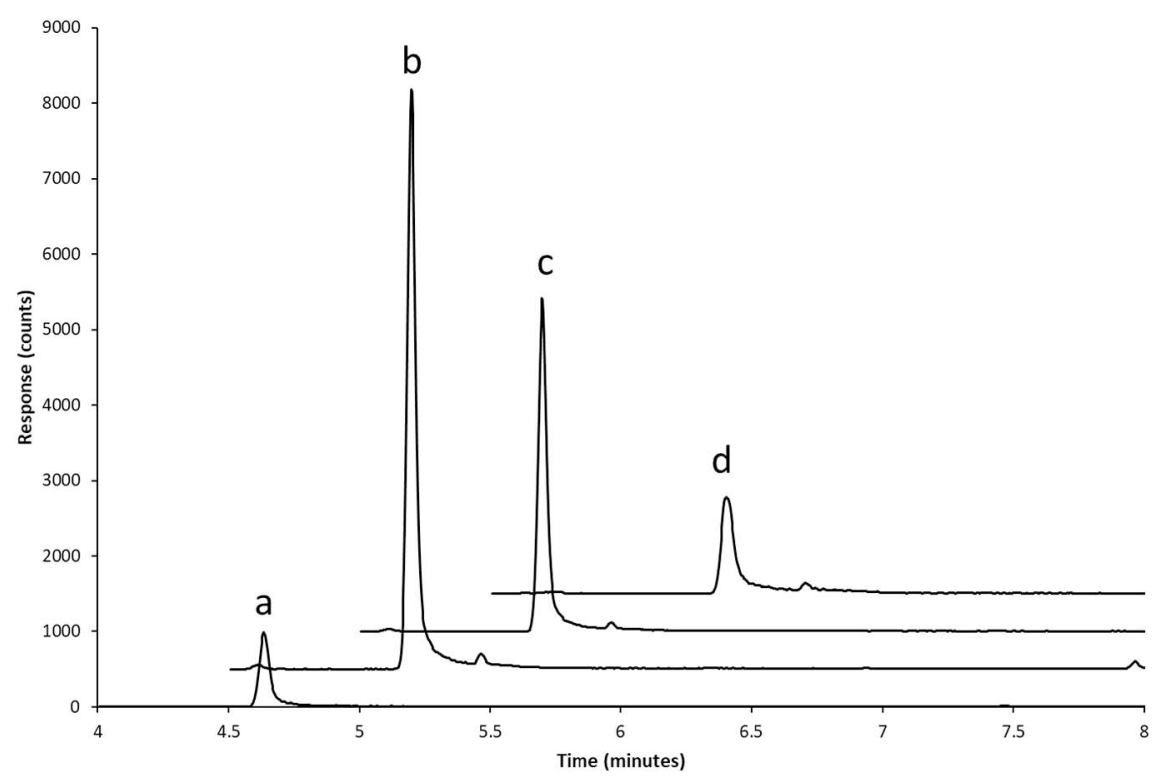

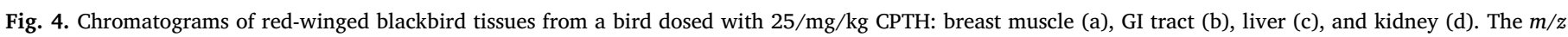
$140.9 \rightarrow 106.2$ MRM transition is shown.

Table 2

Detection and quantitation limits for red-winged blackbird tissue analyzed using GC/MS/MS.

\begin{tabular}{lcc}
\hline Tissue type & Detection limit & Quantitation limit \\
\hline GI tract & $4.3 \mathrm{ng} / \mathrm{g}$ & $14 \mathrm{ng} / \mathrm{g}$ \\
Liver & $2.6 \mathrm{ng} / \mathrm{g}$ & $8.7 \mathrm{ng} / \mathrm{g}$ \\
Breast muscle & $3.2 \mathrm{ng} / \mathrm{g}$ & $11 \mathrm{ng} / \mathrm{g}$ \\
Kidney & $5.9 \mathrm{ng} / \mathrm{g}$ & $20 \mathrm{ng} / \mathrm{g}$ \\
\hline
\end{tabular}

stronger and more consistent sample responses. Use of $p$-toluidine also aided in the recovery of the CPT from the SPE cartridge by minimizing interactions of the CPT with any active sites in the cartridge.

\subsection{Method validation}

\subsubsection{Selectivity}

Typical MRM chromatograms of control tissues fortified at $50 \mathrm{ng} / \mathrm{g}$ for GI tract, liver, and breast muscle and $125 \mathrm{ng} / \mathrm{g}$ for kidney and from a red-winged blackbird dosed with $25 \mathrm{mg} / \mathrm{kg}$ of CPTH are presented in Figs. 3 and 4. There were matrix peaks observed near the retention time of CPT in most of the matrices tested (Fig. 2). In most cases, these peaks occurred after the retention time for CPT and did not interfere with the detection of CPT. In some cases (in particular for breast muscle samples) peaks were observed at the retention time of CPT. These peaks were attributed to either carry-over in the GC inlet or matrix peaks in the samples. Under the conditions specified, the retention times of $d_{6}$-CPT and CPT were $4.6 \mathrm{~min}$.

\subsubsection{Detection and quantification limits}

The detection limit (DL) for CPTH in red-winged blackbird tissues

Table 3

Average regression coefficients $(n=18)$.

\begin{tabular}{lc}
\hline Coefficient & Mean \\
\hline $\mathrm{a}$ & $0.00156 \pm 0.00051$ \\
$\mathrm{~b}$ & $2.08 \pm 0.087$ \\
$\mathrm{c}$ & $0.022 \pm 0.032$ \\
\hline
\end{tabular}

was estimated from the mean chromatographic response of control samples compared to control samples that had been fortified to $20 \mathrm{ng} / \mathrm{g}$ with CPTH for GI tract, liver, and breast muscle or $50 \mathrm{ng} / \mathrm{g}$ with CPTH for kidney. The DL was defined as the concentration of CPTH required to generate a signal equal to $3 \times$ the baseline noise (measured peak-topeak) observed in the baseline at the retention time of CPT in the control samples. The quantitation limit (QL) for CPTH in red-winged blackbird tissues was estimated in a similar fashion to as the DL with the multiplier of $10 \times$ baseline noise used instead of $3 \times$. The DL and QL for GI tract, kidney, liver and breast muscle of red-winged blackbirds are shown in Table 2.

\subsubsection{Linearity}

The average of all calibration curves was determined $(n=18)$ where Y represents the ratio of concentration of CPTH to $d_{6}-\mathrm{CPTH}$ and $\mathrm{X}$ represents the ratio of CPT area response to $d_{6}$-CPT area response (Table 3). Calibration was achieved with a $1 / \mathrm{x}$ weighted quadratic

Table 4

Precision and accuracy of CPTH in red-winged blackbird tissues.

\begin{tabular}{|c|c|c|c|c|c|}
\hline Matrix & $\mathrm{n}$ & Target (ng/g) & $\begin{array}{l}\text { Observed } \\
\text { (ng/g) }\end{array}$ & $\begin{array}{l}\text { Precision } \\
\text { (RSD, \%) }\end{array}$ & Accuracy (RE, \%) \\
\hline \multirow[t]{5}{*}{ Breast muscle } & 7 & 20 & $21.3 \pm 6.7$ & 31.5 & 6.50 \\
\hline & 9 & 50 & $43.1 \pm 3.1$ & 7.19 & 13.8 \\
\hline & 7 & 100 & $87.0 \pm 2.5$ & 2.87 & 13.0 \\
\hline & 7 & 300 & $294 \pm 14$ & 4.76 & 2.00 \\
\hline & 7 & 1000 & $889 \pm 42$ & 4.72 & 11.1 \\
\hline \multirow[t]{5}{*}{ GI tract } & 7 & 20 & $20.7 \pm 0.74$ & 3.57 & 3.50 \\
\hline & 7 & 50 & $48.7 \pm 3.9$ & 8.01 & 2.60 \\
\hline & 7 & 100 & $95.2 \pm 2.0$ & 2.10 & 4.80 \\
\hline & 7 & 300 & $298 \pm 4.1$ & 1.38 & 0.67 \\
\hline & 7 & 1000 & $988 \pm 37$ & 3.74 & 1.20 \\
\hline \multirow[t]{5}{*}{ Kidney } & 7 & 50 & $39.4 \pm 7.6$ & 19.3 & 21.2 \\
\hline & 7 & 125 & $86.1 \pm 7.9$ & 9.18 & 13.9 \\
\hline & 7 & 250 & $219 \pm 27$ & 12.3 & 12.4 \\
\hline & 7 & 750 & $697 \pm 33$ & 4.73 & 7.07 \\
\hline & 7 & 2500 & $2341 \pm 80$ & 3.42 & 6.36 \\
\hline \multirow[t]{5}{*}{ Liver } & 6 & 20 & $20.2 \pm 1.3$ & 6.44 & 1.00 \\
\hline & 7 & 50 & $48.5 \pm 3.4$ & 7.01 & 3.00 \\
\hline & 7 & 100 & $98.6 \pm 1.3$ & 1.32 & 1.40 \\
\hline & 7 & 300 & $309 \pm 11$ & 3.56 & 3.00 \\
\hline & 6 & 1000 & $1060 \pm 66$ & 6.23 & 6.00 \\
\hline
\end{tabular}


Table 5

Mean CPTH residue levels (ng/g) in red-winged blackbirds following a single, oral dose.

\begin{tabular}{|c|c|c|c|c|c|}
\hline Dose level & & Kidney & GI tract & Liver & Breast muscle \\
\hline \multirow[t]{4}{*}{$12.5 \mathrm{ng} / \mathrm{g}$} & Mean $\pm s d=$ & $78.9 \pm 45.5$ & $66.6 \pm 30.1$ & $85.1 \pm 36.1$ & $23.8 \pm 14.9$ \\
\hline & Range $=$ & 18-126 & 6.83-110 & 19.8-148 & 4.9-50 \\
\hline & $\mathrm{RSD}=$ & $58 \%$ & $45 \%$ & $42 \%$ & $63 \%$ \\
\hline & $\mathrm{n}=$ & 8 & 8 & 8 & 8 \\
\hline \multirow[t]{4}{*}{$25 \mathrm{ng} / \mathrm{g}$} & Mean $\pm s d=$ & $297 \pm 199$ & $585 \pm 820$ & $215 \pm 125$ & $42.2 \pm 27.2$ \\
\hline & Range $=$ & $55.2-676$ & $102-2400$ & 75.8-441 & 10.3-79.5 \\
\hline & $\mathrm{RSD}=$ & $67 \%$ & $140 \%$ & $58 \%$ & $66 \%$ \\
\hline & $\mathrm{n}=$ & 8 & 7 & 8 & 8 \\
\hline \multirow[t]{4}{*}{$37.5 \mathrm{ng} / \mathrm{g}$} & Mean $\pm s d=$ & $356 \pm 124$ & $559 \pm 684$ & $317 \pm 145$ & $49.5 \pm 21.0$ \\
\hline & Range $=$ & 203-570 & $107-2170$ & 167-571 & 26.4-89.5 \\
\hline & $\mathrm{RSD}=$ & $35 \%$ & $122 \%$ & $46 \%$ & $42 \%$ \\
\hline & $\mathrm{n}=$ & 8 & 8 & 8 & 8 \\
\hline
\end{tabular}

regression analysis $\left(\mathrm{Y}=\mathrm{aX} \mathrm{X}^{2}+\mathrm{bX}+\mathrm{c}\right)$ with correlation coefficients of 0.999 or better. The calibration curve was linear over the range of $5.15 \mathrm{ng} / \mathrm{mL}$ to $5300 \mathrm{ng} / \mathrm{mL} \mathrm{CPTH}$. The accuracy of all concentrations in the calibration curve was $<10 \%$.

\subsubsection{Precision and accuracy}

The precision and accuracy values for recovery of CPTH from redwinged blackbird tissues demonstrated good method performance across all levels (Table 4). The samples were analyzed over the course of a 5 month period of time. The average precision of $\mathrm{CPTH}$, represented by the relative standard deviation of the observed concentrations, was $7.2 \%$ and the average accuracy, represented by the relative error, was $6.7 \%$. Therefore, the validated method provided acceptable precision and accuracy for the determination of CPTH in tissues.

ANOVA results from a GLM analysis (SAS General Linear Model (GLM); SAS Institute, Inc., Cary, NC) demonstrated a significant effect from tissue type $(\mathrm{F}=12.96 ; \mathrm{p} \leq 0.0001)$, fortification level $(\mathrm{F}=2.95$; $\mathrm{p}=0.0229)$, and from the interaction of tissue and level $(\mathrm{F}=2.33$; $\mathrm{p}=0.0101)$. Recovery levels for liver and GI tract were not significantly different from each other $(\alpha=0.05)$. Recovery from breast muscle tissue was lower than both liver and GI tract, but higher than that for kidney. Recovery from kidney tissue was lower than any other matrix.

\subsubsection{Bird dosing study}

Samples from the control exposure group had observable CPTH responses in several cases, although they were below the QL. These responses were likely due to the presence of matrix peaks in the chromatograms or from instrument carry over effects (Fig. 2). Values below the DL were reported as not detected. For statistical analysis of these samples, a value of one-half of the DL was used. Results between the DL and QL were considered to be qualitative only. Therefore, results between these two values were only reported to two significant digits where other results used three significant digits.

The residue levels observed in the in-vivo study (Table 5) were higher than anticipated, particularly in the GI tract. Given the rapid excretion observed in the results from a radio-tracer excretion study [6], there was an expectation that the GI tract residues would be quite low. There are two possible explanations for this discrepancy. Firstly, the dose administered in the radio-tracer study was $3.6 \mathrm{mg} / \mathrm{kg}$ while the low dose group in the current study was $12.5 \mathrm{mg} / \mathrm{kg}$. Since the time to death is dose dependent for $\mathrm{CPTH}$, the higher dose used in the current study led to all but one of the dosed birds being found dead by the morning following administration of the dose. The lone bird in the low dose group which survived the three days of the study had lower residues in all three tissues compared to other birds in the low group. This higher dose likely contributed to less of the CРTH being excreted prior to death.

\section{Conclusion}

A method for the quantitation of CPTH in bird tissues was developed and validated. The method was successfully used to quantitate residue levels of CPTH in red-winged blackbirds exposed to an oral dose at three levels. The method made some improvements on previous methods used for CPTH residue determinations. During a previous study at NWRC designed to mimic a field exposure in mourning doves (Zenaida macroura), the results for breast muscle samples were nearly all below the $70 \mathrm{ng} / \mathrm{g}$ QL reported for the method used [2]. The current method has a QL in breast muscle which is significantly lower (14 ng/ $\mathrm{g}$ ), demonstrating a clear improvement on previous methods. This was likely due to the use of tandem mass spectrometer rather than the mass selective detector (single quadrupole) used in the literature method. The results for GI tract samples in the 2006 research were above the QL for the method, but both tissues demonstrated RSD values near 50\%. This was consistent with the results from the current study. Also similar between the current study and those in the literature was the difference in concentration of CPTH observed between GI tract and breast muscle. In all cases, the concentration in GI tract was much larger than that for breast muscle in an individual bird.

The method represents a significant improvement on previous methods. The DL for the current method represents a significant improvement on previous methods. The DL for previously reported methods [4,7] were between 12 and $25 \mathrm{ng} / \mathrm{g}$ for the matrices tested. The DL for the method described varies between 2.6 and $5.9 \mathrm{ng} / \mathrm{g}$ (Table 2). Previous methods relied on single ion monitoring (SIM) for detection of residues. The described method utilizes tandem mass spectrometry which provides added certainty of detected residues in the form of qualifier transitions. The lowered DL and use of quantifier ion confirmation provide added confidence to the low level residues often observed in field samples and provide a valuable tool in future studies to assess field exposures from the use of $\mathrm{CPTH}$ as a bird control agent.

\section{References}

[1] J.J. Johnston, D.B. Hurlbut, M.L. Avery, J.C. Rhyan, Methods for the diagnosis of acute 3-chloro-p-toluidine hydrochloride poisoning in birds and the estimation of secondary hazards to wildlife, Environ. Toxicol. Chem. 18 (1999) 2533-2537.

[2] R.S. Stahl, J.J. Johnston, The effect of time on the recovery of DRC-1339 residues from tissues collected from decomposing mourning dove carcasses, Proceedings of the Vertebrate Pest Conference, 33 2006, pp. 447-449.

[3] T.J. DeCino, D.J. Cunningham, E.W. Schafer Jr., Toxicity of DRC-1339 to starlings, J. Wildl. Manag. 30 (1966) 249-253.

[4] R.S. Stahl, T.W. Custer, P.A. Pochop, J.J. Johnston, Improved method for quantifying the avicide 3-chloro-p-toluidine hydrochloride in bird tissues using a deuterated surrogate/GC/MS method, J. Agric. Food Chem. 50 (2002) 732-738.

[5] J.D. Eisemann, G.M. Linz, J.J. Johnston, Non-target hazard assessment using DRC1339 avicide to manage blackbirds in sunflower, in: John J. Johnston (Ed.), Pesticides and Wildlife, ACS Symposium Series, 771 2001, pp. 197-211.

[6] D.A. Goldade, J.D. Tessari, J.J. Johnston, Absorption, distribution, and excretion of 
$\left[{ }^{14} \mathrm{C}\right]$-3-chloro-4-methylaniline hydrochloride in two species of birds following a single oral dose, J. Agric. Food Chem. 52 (2004) 8074-8080.

[7] D.B. Hurlbut, J.J. Johnston, S.R. Daniel, J.N. Tawara, A gas chromatography/mass spectrometry method for the quantitation of 3-chloro-p-toluidine hydrochloride (CPTH) in birds using a deuterated surrogate, J. Agric. Food Chem. 46 (1998)
4610-4615.

[8] K. Smith, K. Fry, Para-selective mononitration of alkylbenzenes under mild conditions by use of benzoyl nitrate in the presence of a zeolite catalyst, Tetrahedron Lett. 30 (1989) 5333-5336. 